\title{
O ENQUADRAMENTO DA GREVE DOS PROFESSORES ESTADUAIS NAS PÁGINAS DO JORNAL ESTADO DE MINAS
}

\author{
MARTA REGINA MAIA \\ Universidade Federal de Ouro Preto \\ Mariana, Minas Gerais, Brasil. \\ e-mail:marta@martamaia.pro.br \\ MARIA APARECIDA PINTO \\ Universidade Federal de Minas Gerais \\ Belo Horizonte, Minas Gerais, Brasil. \\ e-mail:mariajornalismo2009@yahoo.com.br
}


O ENQUADRAMENTO DA GREVE DOS PROFESSORES ESTADUAIS NAS PÁGINAS DO JORNAL ESTADO DE MINAS

Resumo: Esse artigo mostra o enquadramento dado pelo jornal Estado de Minas à greve dos professores da rede pública estadual de Minas Gerais, em 2011. Foram avaliadas as matérias veiculadas, com o objetivo de perceber como os sujeitos que representam as fontes para as matérias são agenciados pela ação acontecimental, bem como se articula a construção do movimento social de acordo com os quadros de referência do veículo.

Palavras-chave: acontecimento; enquadramento; jornalismo; movimentos sociais; greve.

EL MARCO DE LA HUELGA DE LOS MAESTROS ESTATALES EN LAS PÁGINAS DEL PERIÓDICO ESTADO DE MINAS

Resumen: En este trabajo se muestra el marco proporcionado por lo periódico Estado de Minas a la huelga de los maestros de las escuelas públicas estatales del estado de Minas Gerais, en 2011. Se evaluaron los artículos publicados, con el fin de entender cómo los sujetos que representan las fuentes de la materia se promocionan por la acción acontecimental así como la construcción del movimiento social se articula de acuerdo con los marcos del vehículo.

Palabras clave: acontecimiento, marco, periodismo, movimientos sociales; huelga.

THE FRAMEWORK OF THE STATE TEACHER'S STRIKE IN THE PAGES OF THE ESTADO DE MINAS NEWSPAPER

Abstract: This paper shows the framework conferred by the Estado de Minas newspaper for the strike of teachers in the state public education system of Minas Gerais, in 2011. It was evaluated the articles published, with the aim of understand how the subjects that represent the sources for the newspaper reports are agencied by the action's event, as well as the construction of the social movement articulates according to the vehicle's reference of frames.

Keywords: event; framework; journalism; social movements; strike. 


\section{INTRODUÇÃO}

A sociedade contemporânea observa a explosão de acontecimentos de forma ininterrupta. O intenso fluxo de informações alarga, freneticamente, o campo de visão dos sujeitos igualmente em movimento, que possuem a alternativa de participar da realidade a partir da perspectiva proporcionada pelo enquadramento utilizado na notícia pelos diversos meios jornalísticos como o impresso, radiofônico, televisivo ou a internet. Por meio desse processo, o fato passa a ser real, no sentido de fazer parte do conhecimento do mundo compartilhado dentro da sociedade, para um número considerável de pessoas. A informação sobre o que está ocorrendo no espaço em que se vive influencia nos modos de pensar e, consequentemente, na forma de agir.

Deve-se ressaltar que não é possível ao jornalismo informar sobre todos os fatos, assim como não é possível ao ser humano ter conhecimento sobre tudo o que ocorre em seu entorno. Nesse sentido, o que recebe espaço no trabalho desenvolvido pelos jornalistas denota e, sobretudo, conota um conjunto amplo de significações que compõem o processo pelo qual se constrói a verdade de forma interpretativa. A verdade, portanto é constructo não estabelecido, mas interpretado. É por causa desta relação que o enquadramento influencia a leitura dos sujeitos sobre a imensa gama de acontecimentos cotidianos.

O enquadramento é enfocado, neste trabalho, como o ângulo de direcionamento que estrutura a notícia e os mecanismos que esta oferece ao leitor. Isto é, o recorte da realidade que se realiza, atendendo às demandas de sentido e significação, para compor uma nova realidade construída pelos sujeitos que têm acesso ao material publicado. Na definição de Todd Gitlin: "enquadramentos são padrões persistentes de interpretação através dos quais os manipuladores de símbolos organizam discursos de forma rotineira" (GITLIN apud PORTO, 2004, p. 12). Desta forma, o discurso jornalístico é organizado a partir de certos parâmetros que buscam garantir legitimidade diante do receptor, dado que a comunicação ocorre a partir de processos sociais.

A ação social depende do conhecimento acumulado, das experiências vivenciadas, ou seja, da formação pessoal de cada sujeito. A informação é base para tal processo e o jornalismo é um dos principais responsáveis pela efetivação de ações sociais, pois quando informa realiza uma de suas participações na construção do espaço público, já que a missão fundadora do campo provém 
do ideal iluminista de proporcionar esclarecimento aos cidadãos. É importante notar que o fazer jornalístico é pautado por acontecimentos que rompem com os padrões da normalidade; fatos inesperados que, de alguma forma, podem interferir na vida das pessoas e, portanto, reverberar socialmente.

Assim, é possível pensar como o acontecimento contribui na construção da realidade interferindo no comportamento do sujeito que se posiciona e age perante a forma como o ocorrido é enquadrado, não é ignorado o processo interpretativo necessário ao entendimento do material jornalístico o que colocaria o "receptor" como mero agente passivo do processo de produção de informação - a que o "receptor" tem acesso, mas o enquadramento contribui substancialmente para o viés interpretativo decorrente do contato com a notícia. Nesse contexto, encontra-se o movimento grevista promovido pelos servidores da rede estadual de ensino de Minas Gerais. Para a análise foram avaliadas 24 matérias e reportagens relativas ao tema que foram veiculadas no jornal Estado de Minas, caderno Gerais, no período de 6 de agosto a 24 de setembro de 2011, data do final da greve. Pretende-se, desse modo, perceber como os sujeitos que constituem fonte para as matérias e reportagens que abordam a greve são agenciados pela ação acontecimental, bem como se articula a construção do movimento social de acordo com quadros de referência, que refletem posições claramente delimitadas e de fácil identificação no período em foco.

Antes, porém, de tratar o objeto da pesquisa, é necessária a realização de considerações teóricas acerca das linhas de investigação que guiaram a construção do presente estudo, tecendo algumas considerações sobre as concepções que orientaram a análise das reportagens.

\section{ACONTECIMENTO E ENQUADRAMENTO: CARACTERÍSTICAS E IMPLICAÇÕES}

O acontecimento é construído a partir da "conclusão" do fato. Após o caos que o envolve impedindo a sua compreensão - uma vez que os fragmentos do ocorrido encontram-se dispersos pelo espaço -, pode-se executar a tarefa de "juntar" as peças para compor o todo e obter uma visão geral que proporcione a obtenção das relações como possíveis causas, envolvidos e desdobramentos do que ocorreu. Nesse processo, pode-se chegar aos diversos sentidos de um acontecimento, segundo Quéré: ao "poder hermenêutico do acontecimento" 
(2005, p. 59). O acontecimento, ao afetar alguém, torna-se filão de reações e respostas que possuem implicação direta na sociedade:

Terá podido tocar sujeitos individuais ou coletivos, fazer vítimas e sobreviventes, provocar nos indivíduos e nas coletividades, sensações, emoções e reações, satisfazer ou desiludir, alegrar ou horrorizar, satisfazer ou desesperar, aterrar as 'vivências' para o bem ou para o mal, resolver a situação das pessoas ou colocar-lhes novos problemas (QUÉRÉ, 2005, p. 62).

No estudo do acontecimento, deve-se debruçar-se sobre o que ele possibilita: se instaurou novos questionamentos e colocou em pauta aspectos antes ignorados ou marginalizados. Os fatos inesperados e adversos possuem maior poder de revelação e de transformação, na medida em que proporcionam a pesquisa, a apuração e o aperfeiçoamento cuja finalidade é não repetir o erro, o que se baseia na constatação de R. Koselleck sobre vencedores e vencidos e suas relações, respectivamente, com curto e longo prazo: "A condição de vencido detém, visivelmente, um potencial inesgotável de crescimento do conhecimento." (KOSELLECK, 1997 apud Quéré, 2005, p. 64). Ao "romper” com a ideia construída de normalidade, o acontecimento implica a revelação dos distintos papeis sociais atuantes na sociedade. Processo pelo qual se permite a identificação dos enquadramentos apresentados nas matérias de jornais ou em outros veículos comunicacionais. Trata-se da análise do recorte conferido nestes produtos de informação.

O enquadramento organiza o mundo respondendo de forma lógica e significativa à pergunta: o que está acontecendo? Da mesma forma, a produção jornalística aponta para a linha editorial do veículo contribuindo de forma essencial para a pergunta citada acima, porém dentro de outro viés. O viés da análise específica de um veículo jornalístico. É dentro dessa perspectiva, que se realiza o estudo da cobertura jornalística do Estado de Minas sobre o movimento grevista dos professores da rede estadual de ensino, com a clareza que a análise de enquadramento ficaria mais completa com a dimensão da pesquisa de recepção, o que, entretanto, no escopo desta pesquisa não foi possível de ser realizada. 


\section{A GREVE: ENTRE BONS E MAUS}

Antes de analisar a construção jornalística do acontecimento é necessário entender o processo que acarretou a paralisação dos serviços prestados pelos professores. A greve dos professores da rede pública estadual de ensino teve início em 8 de junho de 2011 devido a um impasse entre o governo de Minas Gerais e os docentes com relação à proposta de reajuste salarial apresentada pelo primeiro. O movimento é resultado da luta dos educadores pelo cumprimento do piso salarial nacional. Eles reivindicavam um piso de $\mathrm{R} \$ 1.597,87$ contra o salário de $\mathrm{R} \$$ de 369,89 que recebiam, segundo o Sindicato Único dos Trabalhadores em Educação de Minas Gerais (Sind-Ute/MG).

A secretária de Estado de Educação, Ana Lúcia Gazzola, afirmou que a remuneração inicial era de $\mathrm{R} \$ 1.122$ para uma jornada de 24 horas para professores formados em nível médio. Os profissionais com nível superior recebiam subsídio inicial de R\$1.320 para a mesma carga horária. Estas informações foram publicadas na retranca da matéria "Corrida para garantir Enem" - Estado diz pagar mais que o piso - página 28 da edição de 9 de agosto de 2011. A partir destas considerações acerca de questões salariais - que implicam assuntos mais complexos que não poderiam ser tratados no trabalho - pode-se iniciar a análise da cobertura realizada pelo impresso.

O jornal Estado de Minas, no caderno Gerais, apresentou matérias e reportagens que demonstravam ampla cobertura do processo, indicando "passo a passo" como caminhavam as negociações, as manifestações de professores, alunos e pais de afetados pelo movimento grevista, além de informar sobre as propostas governamentais para "sanar o problema". As notícias também foram pautadas pelo registro dos transtornos gerados pela greve. Problemas relacionados a engarrafamentos decorrentes de tumultos causados por passeatas dos servidores públicos em greve e os custos adicionais que famílias de alunos passaram a arcar (com a transferência para outras instituições de ensino, pagamento de cursos preparatórios para o Enem - Exame nacional do ensino médio, no caso de estudantes que cursavam o $3^{\circ}$ ano do ensino médio, por exemplo).

O trabalho jornalístico apresenta-se rico em material para análise, são 24 matérias selecionadas aleatoriamente que tratam sobre o assunto no período de 6 de agosto a 24 de setembro. A perspectiva adotada pelo impresso revela- 
se marcada pelo caráter de oposição ao movimento de reivindicação de melhorias nas condições salarias promovido pelos professores. Angulação que pode ser constatada por meio das manchetes, das chamadas de capa, dos "chapéus" (palavras ou expressões que vêm acima das manchetes) e dos "olhos" (frases destacadas no interior do texto), elementos constituintes da produção noticiosa que resumem os valores centrais (os pontos chave) veiculados na matéria ou reportagem em questão. Dessa forma, apresentam-se seis matérias, de forma descritiva e comentada, que se encontram entre o corpus de pesquisa com a finalidade de propor um processo de detalhamento e contextualização do método de exame e do tema abordado, além do contato com o próprio objeto analisado.

Como exemplo a manchete do dia 6 de agosto, página 23, "Associação quer ação contra greve" que intitula matéria de Pedro Ferreira. Nesta, uma das fontes é o presidente da Federação das Associações de Pais e Alunos de Escolas Públicas de Minas Gerais (Fapaemg), Mário de Assis, que considera o movimento uma "covardia social". Outro entrevistado é o promotor Celso Penna que fala de forma ponderada, mas ressalta que a escola serve se ensina e o professor pode fazer greve (se legal), entretanto, o aluno deve ser mantido na escola por outros meios. Ambas as fontes apresentam falas literais enquanto que a terceira ouvida, o sindicato da categoria, aparece apenas no final da matéria informando que o valor arrecadado com o governo do estado é para repor o salário de profissionais que sofreram cortes orçamentários.

A ausência de polifonia na construção das matérias pode ser percebida de forma evidente em outras informações divulgadas por meio da matéria de 9 de agosto, quando o problema da greve é voltado para o Enem, ou seja, como o movimento prejudicou o processo preparatório para o Exame. A chamada de capa prenuncia a angulação da matéria: “Greve ameaça até o Enem. Por causa da paralisação de mais de dois meses na rede estadual, associação de pais vai à justiça para adiar o Enem".

Na página 28, a reportagem de Flávia Ayer e Guilherme Gouveia, “Corrida para garantir Enem", apresenta 5 fontes principais: o presidente da Federação das Associações de Pais e Alunos de Escolas Públicas de Minas Gerais (Fapaemg), a Secretaria de Estado da Educação, a coordenadora geral do Sind-Ute/ MG (Beatriz Cerqueira), a secretária estadual de Educação (Ana Lúcia Gazzola) 
e quatro estudantes (de 16 e 17 anos) do terceiro ano do ensino médio. Com exceção da coordenadora geral do Sind-Ute/MG - que afirmava que naquele momento da greve havia $50 \%$ da rede parada e apontava falta de diálogo por parte do governo, uma vez que eles ficaram seis meses esperando negociação sobre o piso salarial - todas as outras fontes corroboravam a mesma visão sobre a greve como pode ser constatado a seguir.

O tom da produção jornalística explicita-se com expressões da própria reportagem, que caracterizava a greve como: movimento intransigente e político para constranger o governo, segundo a secretária de educação; na visão dos alunos há desamparo: "descaso dos professores e do governo", "a concorrência já é desleal, não temos tempo para desperdiçar com um problema que não causamos". A matéria traz, ainda, uma retranca com viés governamental que reforça a posição da publicação: "Estado diz pagar mais que o piso", com informações que contradizem as falas dos grevistas e seus argumentos.

Em 18 de agosto, a reportagem da página 2, "Estudantes driblam greve", de autoria de Júnia Oliveira, informa sobre alternativas que alunos adotaram para recuperar o tempo perdido e garantir o Enem. As fontes que participaram do processo de informação são três alunas do ensino médio, a mãe de uma das alunas entrevistadas e, em uma seção à parte denominada "Palavra de especialista" com o título de "Aprendizagem comprometida", o coordenador do curso de pedagogia do UNI - BH e Mestre em Educação, Carlos Donizetti, que desenvolve a afirmação de que "toda greve gera prejuízos". Na reportagem, ícones de ótimos estudantes são apresentados como os únicos prejudicados pela paralisação e possuem a fala minuciosa de um especialista que justifica de forma argumentativa a situação que estes se encontram. As produções que se seguem mantêm a mesma orientação.

Em 24 de agosto, o caderno Gerais publicou na página 21 reportagem de Flávia Ayer, "Pacote tenta acabar com greve no estado". Nesta, percebe-se que a imagem construída é a de um governo diplomático que deseja negociar e fazer concessões para alcançar um “bem maior”. O processo inicia-se na linha fina: "com objetivo de encerrar um impasse que já beira 80 dias, governo propõe conjunto de medidas buscando corrigir distorções no subsídio". Percebese a não alteração nas fontes e a ausência de polifonia, pois, neste caso, há somente uma fala dos grevistas e todas as outras representam a outra vertente: 
governo do estado (medidas que visam encerrar a greve); Sind-Ute (medidas não refletem as reivindicações da categoria) colocado como impassíveis; secretária de Estado e Planejamento e Gestão (Renata Vilhena): o governo cumpre compromissos; secretária de Estado da Educação (Ana Lúcia Gazzola): “os profissionais [que] reconheçam as melhorias e retornem às salas de aula".

A outra matéria da mesma página apontou para o transtorno no trânsito. "Protesto desafia paciência em 381", autoria de Pedro Ferreira, informou sobre tumulto e engarrafamento de $5 \mathrm{~km}$ na BR 381 que provocou revolta em motoristas. Nesse sentido, os entrevistados apontaram para problemas pontuais e individuais de pessoas que foram afetadas pela mobilização como o atraso para o trabalho. A matéria é composta por reclamações dos entrevistados (um empresário, um caminhoneiro, um inspetor da Polícia Rodoviária Federal). No final da matéria, fornece-se a justificativa da assessoria de imprensa do SindUte/MG sobre a escolha do local para a manifestação. De acordo com este, os professores escolheram o local devido ao grande fluxo de motoristas e a proposta era de diálogo com as pessoas.

Com a análise realizada, por meio dos casos exemplos selecionados, podese perceber como a greve estruturou-se como acontecimento e foi enquadrada pelo impresso em questão. A ação dos professores por quebrar a normalidade "criança na escola" constitui acontecimento jornalístico, do mesmo modo como ao infringir a normalidade do trânsito, com passeatas em avenidas, também categoriza a ação como acontecimento digno de cobertura jornalística. Ricardo Fabrino Mendonça aponta que

\begin{abstract}
interpretar um movimento social a partir do conceito de acontecimento é percebê-lo como descontinuidade que irrompe no tecido social, permitindo a reinterpretação de elementos que o precederam e dos campos de possibilidade que o sucederão. Ao reconfigurar, interpretativamente, fragmentos da realidade social, tais agências coletivas afetam o contexto em que se situam e os próprios sujeitos que as constituem, ao mesmo tempo em que são por eles edificadas. (2007, p. 118 [grifo do autor]).
\end{abstract}

A greve também é acontecimento por afetar um estado nacional inteiro, uma vez que a proporção de paralisação, em determinado momento, segundo o sindicato que representa os professores, era de 50\%, interferindo no hábito 
dos indivíduos e reverberando socialmente. "Ato que suscita a palavra social; que a estimula e a faz proliferar (...). Ora, a narrativa jornalística não é senão a consagração e o prolongamento desse impulso de falar, assim como sua organização". (FRANÇA, 1998, p. 133). A paralisação apresentou valor notícia e, portanto, foi enquadrada como acontecimento sobre o qual as pessoas foram "forçadas" a se posicionar ou a emitir opinião baseadas na informação que adquiriam de impressos, rádios entre outros meios.

A cobertura jornalística construiu dicotomias arquitetando-se duas representações que se opõem com veemência: bons e maus. Nesse processo, estão implícitos lugares, representações e funções sociais que dependem da "ocupação" da qual o sujeito se vale. De acordo com Jacques Rancière, "ter esta ou aquela 'ocupação' define competências ou incompetências para o comum”. (2005, p. 16), ou seja, para a sociedade de modo geral. Desse modo, criam-se "heróis" e "vilões".

Na tabela abaixo, formulou-se um quadro em que se correlacionam as construções jornalísticas (manchetes e linhas finas classificadas como construções discursivas) às imagens associadas a estas (governo estadual, alunos, trabalhadores prejudicados pelas manifestações, associações de pais de alunos, etc.) de forma a dinamizar a apresentação dos dados referentes às reportagens não tratadas de forma detalhada no artigo. Assim, podem ser citados alguns "heróis": a Federação das Associações de Pais e Alunos de Escolas Públicas de Minas Gerais (Fapaemg), que tenta agir judicialmente para encerrar a greve; o governo estadual que tenta negociar com os grevistas; os estudantes que se adaptam à situação para não ficarem muito defasados no ensino e os pacientes motoristas que enfrentam engarrafamentos ocasionados pelo tumulto provocado pelas manifestações dos professores.

Mas há apenas um vilão: os grevistas. São estes que não aceitam as propostas do governo, não consideram a situação dos alunos, não calculam todos os danos. Nas produções jornalísticas veiculadas pelo jornal marcadas por expressões de repúdio à ação dos professores, distinguem-se a seleção e a exclusão realizadas no processo de construção das notícias que desfavorecem a significação do movimento. Esses mecanismos constroem as duas representações apontadas anteriormente. 
Tabela I

\begin{tabular}{|c|c|}
\hline Fontes: "heróis" & Construções jornalísticas \\
\hline $\begin{array}{l}\text { Associações de Pais e Alunos de Escolas } \\
\text { Públicas de Minas Gerais (Fapaemg) }\end{array}$ & $\begin{array}{l}\text { "Associação quer ação contra greve" (man- } \\
\text { chete) } 6 \text { de agosto }\end{array}$ \\
\hline Governo do Estado & $\begin{array}{l}\text { "Grevistas terão substitutos" (manchete) } \\
10 \text { de agosto }\end{array}$ \\
\hline Estudantes afetados pela paralisação & $\begin{array}{l}\text { "Estudantes driblam greve" (manchete) } 18 \text { de } \\
\text { agosto }\end{array}$ \\
\hline Governador do Estado & $\begin{array}{l}\text { "Reforço pela TV" (manchete) } 30 \text { de agosto } \\
\text { "Anastásia anuncia que alunos do ensino mé- } \\
\text { dio fora da escola há } 84 \text { dias terão aulas pela } \\
\text { Rede Minas a partir do dia 12. Procurador-geral } \\
\text { pode intermediar negociações." (linha fina) }\end{array}$ \\
\hline Tribunal de Justiça & $\begin{array}{l}\text { "Tribunal mantém contratação" (manchete) } \\
\text { "Justiça nega, pela segunda vez, pedido de sin- } \\
\text { dicato para impedir nomeação de professores } \\
\text { substitutos e garante aulas a estudantes do } \\
3^{\circ} \text { ano do ensino médio que farão provas do } \\
\text { Enem." (linha fina) } \\
6 \text { de setembro }\end{array}$ \\
\hline $\begin{array}{l}\text { Estado de Minas Gerais } \\
\text { (governo do estado) }\end{array}$ & $\begin{array}{l}\text { "Estado terá } 12 \text { mil novos professores" (cha- } \\
\text { mada de capa); "Mais } 12 \text { mil professores" } \\
\text { (manchete) e "Estado anuncia novas contra- } \\
\text { tações temporárias de imediato para garantir } \\
\text { aulas e evitar comprometimento do calendário } \\
\text { escolar até } 2013 \text {. Categoria faz nova assem- } \\
\text { bléia hoje." (linha fina) } 15 \text { de setembro }\end{array}$ \\
\hline Governo & $\begin{array}{l}\text { "Justiça manda parar greve" "Secretaria pre- } \\
\text { parara reposição" e (manchetes) } 17 \text { de setem- } \\
\text { bro }\end{array}$ \\
\hline
\end{tabular}

Tabela II

\begin{tabular}{|l|l|}
\hline Fonte: “vilão" & Construções Jornalísticas \\
\hline $\begin{array}{l}\text { Ausência de fontes: não foram entrevista- } \\
\text { dos professores que estavam em greve }\end{array}$ & $\begin{array}{l}\text { Manifestação paralisa trânsito (manchete) 10 } \\
\text { de agosto }\end{array}$ \\
\hline Ausência de fontes: motivo anterior & $\begin{array}{l}\text { Retorno sem data certa (manchete) 12 de } \\
\text { agosto }\end{array}$ \\
\hline
\end{tabular}




\begin{tabular}{|l|l|}
\hline Ausência de fontes: motivo anterior & $\begin{array}{l}\text { "Volta às aulas para poucos" e "Capital total- } \\
\text { mente parada" (manchetes) 17 de agosto }\end{array}$ \\
\hline Categoria que decide manter greve & $\begin{array}{l}\text { "Impasse continua" e "Trânsito volta a pagar } \\
\text { a conta" (manchetes) } 25 \text { de agosto }\end{array}$ \\
\hline Professores em greve & "81 dias amargos" (manchete) 27 de agosto \\
\hline Promotores do prolongamento da greve & $\begin{array}{l}\text { "Greve pode terminar na justiça" (chamada } \\
\text { de capa) e "Greve vira alvo do MP" (manche- } \\
\text { te) } 1^{\circ} \text { de setembro }\end{array}$ \\
\hline
\end{tabular}

A postura assumida pelo jornal não questiona as causas da greve, os problemas estruturais da educação no país e no estado de forma a contextualizar o que ocorre, como também não traz as implicações da educação no que diz respeito à cidadania e as consequências que um sistema de ensino desestruturado pode gerar no desenvolvimento de um país. A cobertura porta-se no sentido de que há um problema que se "arrasta" gerando conflitos e "vítimas". Um problema de considerável repercussão que precisa de um fim. O impresso desconsidera a importância que os movimentos grevistas possuem na construção histórica dos direitos trabalhistas, assim como desvaloriza a luta por conquistas de interesses coletivos. Privilegiam-se interesses privados e pontuais em vista de um problema que mostra suas consequências em longo prazo, por meio das taxas de desemprego, desigualdade social e de violência, por exemplo.

Ao longo da cobertura, notam-se sinais de um jornalismo que escolheu uma frente para defender. Essa perspectiva alcança seu auge no dia 19 de setembro, quando o portal do jornal veiculou matéria que informava sobre o fim de uma greve que de fato não havia se encerrado. A publicação "Estudantes retomam aulas após mais de 100 dias de greve", de autoria de Paula Sarapu, traz como "linha fina", texto pequeno que segue a manchete: "Justiça considerou paralisação em Minas abusiva e determinou fim de movimento, sob pena de multa, mas sindicato promete recorrer". Outra matéria "Mais de mil professores voltaram às aulas nesta segunda-feira, diz Secretaria", também foi veiculada no mesmo dia no portal.

A notícia sobre os estudantes - publicada às 06ho4min e atualizada às 06h52min do dia 19 de setembro - é uma prova do alinhamento explícito re- 
alizado pelo jornal. A forma como "recortou" os fatos e criou uma realidade digna de seus interesses propõe que o impresso poderia prever o futuro antecipando o resultado da votação da assembleia de professores que ocorreu no dia 20. Evento na qual os funcionários públicos decidiram pela continuidade da greve, mesmo sob decisão judicial que previa multas gradativas pelos dias em que a paralisação fosse mantida.

Em defesa da notícia equivocada, pode-se apontar para a necessidade de atualidade e o caráter do suporte, on-line, em que esta foi publicada. Porém não se pode desconsiderar os aspectos relacionados aos interesses políticos que envolveram a questão assim como não há como tratar o jornalismo apenas pelo aspecto do imediatismo. As notícias envolvem fenômenos, entretanto, compreendem processos. Diante da evidência fornecida pela publicação on-line, é possível concordar com a afirmação de que "o resultado é uma simplificação do próprio jornalismo, que assim se condena ao mundo das aparências e passa a forjar uma realidade adequada aos cânones ideológico-industriais que conformam as rotinas de produção" (MORETZSOHN, 2007, p. 134).

No impresso, as matérias mantinham o mesmo tom; em 24 de setembro, sábado, a chamada de capa "Começa hoje calendário de reposição de aulas" alertava para ao teor da matéria interna da página 23: "Hoje tem reposição de aulas". A "linha fina" da produção completou: "calendário da Secretaria de Educação prevê que alunos da rede pública estadual afetados pela paralisação dos professores voltem às escolas neste sábado para recuperar conteúdo".

A matéria assinada por Guilherme Paranaiba possui como fontes a Secretaria de Estado de Educação (SEE), que forneceu informações sobre a queda de apoio ao movimento; o secretário do governo (Danilo de Castro) que afirmou que não seria necessário demitir os professores grevistas; a assessoria de comunicação do Ministério Público que informou sobre a possibilidade da instituição entrar com pedido de execução da multa, mas não havia data prevista e o Sind-Ute que forneceu informações de que 50\% dos 270 mil servidores continuavam em greve, dado que para o governo a mobilização encontrava-se em declínio. Percebe-se, novamente, o direcionamento na construção da notícia, uma vez que a maioria das fontes fala a favor do governo.

Não foram entrevistados professores que participaram do movimento ou que se opunham a este - o único professor que atuou como fonte estava substi- 
tuindo um grevista. O "lado grevista" possuía direito de voz apenas por meio de informações e pareceres fornecidos pelo sindicato (coordenadores, presidentes ou assessorias). Os principais envolvidos e promotores do movimento não foram entrevistados. Contraditoriamente, "o lado governamental" foi amplamente representado: por alunos insatisfeitos, por pais na mesma posição, por secretários de educação, associação de pais, por cidadãos comuns (trabalhadores) que se sentiam incomodados ou lesados pelos transtornos gerados por passeatas promovidas pelos grevistas e por porta vozes do próprio governo.

A cobertura jornalística sobre a greve foi minuciosa, um acompanhamento diário dentro da função institucionalizada e legitimada dos profissionais desse campo. Porém, o impresso assumiu uma posição ao condenar o movimento grevista que reivindicava direitos de uma categoria trabalhista que se encontra subvalorizada na sociedade contemporânea. A ampla cobertura jornalística é ambígua:

(...) a luz em excesso sugere o pleno acesso à informação, que a treva escondia: assim, diante do que estava oculto, podíamos ser levados a saber que ignorávamos, e com isso despertar para a necessidade de saber; agora, pela aparência da visibilidade total, somos levados a ignorar que não sabemos, e nos consolamos nessa ilusão de saber (MORETZSOHN, 2007, p. 29).

No próximo tópico, aborda-se o jornal Estado de Minas fornecendo-se dados, sobre sua criação e linha editorial, a partir de estudo desenvolvido por Vera França (1998) no livro "Jornalismo e vida social: a história amena de um jornal mineiro" e pelo estudo de Ramiro Queiroz Silveira (2008), na pesquisa "Linha editorial e poder legislativo: o jornal Estado de Minas e a Assembleia Legislativa de Minas Gerais". Pretende-se, com essa abordagem, afinar os apontamentos levantados até o momento sobre a cobertura em foco e a trajetória histórica do veículo.

\section{ESTADO DE MINAS: O JORNAL}

O jornal Estado de Minas surge em 7 de março de 1928; com formato tabloide possuía 12 páginas e apresentava, inicialmente, tiragem de aproximadamente 5 mil exemplares. Vera França aponta o grupo seleto que fundou a sociedade O Estado de Minas \& Cia. Ltda.: 
Juscelino Barbosa era diretor-geral do Banco Hipotecário e Agrícola de Minas Gerais, enquanto Alvaro Pimentel e Pedro Aleixo, jovens advogados e políticos, eram membros do Conselho Deliberativo da Capital, em oposição ao prefeito da época, Cristiano Machado. [...] A empresa era apoiada por um grupo de intelectuais e de políticos muito respeitados, como Milton Campos, Abílio Machado, entre outros (FRANÇA, 1998, p. 105).

Apesar da notoriedade dos proprietários, o jornal enfrentava problemas financeiros decorrentes principalmente de dois fatores: o inconsistente apoio publicitário e a problemática de desvincular a imprensa da influência da política oficial. Havia, ainda, que se enfrentar a concorrência das produções carioca e paulista. No início de 1929, o jornal estava prestes a finalizar os serviços que oferecia. Entretanto por intermédio de apoios políticos, o jornal conseguiu se manter até maio do mesmo ano, quando foi comprado, pelo grupo que se constituiria posteriormente nos Diários Associados, um dos maiores conglomerados jornalísticos da história do Brasil.

Vera França (1998) afirma que não é propósito do trabalho que desenvolveu realizar análise sobre as relações entre o jornal e o poder político, porém acaba trazendo informações interessantes a esse respeito. Uma que merece menção é o fato de que o "cargo de assessor de imprensa do governador cabia sempre aos jornalistas do Estado de Minas, com algumas exceções (...)" (FRANÇA, 1998, p. 110). Estas, segundo a autora, que se baseia em trabalho de Antunes, "Jornalismo político mineiro - os parlamentares da notícia",- referem-se ao governo de Tancredo Neves (em que o assessor foi oriundo do 0 Estado de S. Paulo) e ao governo de Newton Cardoso, quando houve ruptura total do jornal com o governo do estado. A partir dessas informações, pode-se entender e contextualizar a posição e o enquadramento conferido pelo jornal ao movimento grevista dos professores da rede estadual de ensino.

Trata-se de uma abordagem política e como ao jornalismo cabe o papel de mediador a ele também cabe a função de informar sobre o que acontece nessa esfera da realidade. Segundo Ramiro Queiroz Silveira (2008), no processo de construção de informação acerca de acontecimentos propriamente políticos, geralmente, ocorre um processo de assimetria, uma vez que determinados grupos recebem visibilidade e possuem espaço garantido enquanto outros permanecem no silêncio ou são apagados por meio do enquadramento que 
Ihes são conferidos na produção da notícia. A assimetria resultante do processo gera dois paradigmas: o paradigma da manipulação editorial e o paradigma da produção das notícias.

Baseando-se em Afonso de Albuquerque (1998), Ramiro Queiroz Silveira explica os dois padrões. O primeiro paradigma diz respeito aos fatores externos à produção da notícia que resultam em uma cobertura jornalística tendenciosa. O segundo paradigma é caracterizado por dois fatores que se associam: os fatores extra-jornalísticos e a cobertura política dos meios de comunicação. Devem ser considerados, além dos fatores externos à produção da notícia (interesses políticos e/ou econômicos das instituições noticiosas), fatores vigentes na feitura desse tipo de narrativa de forma mais aprofundada. Nesse âmbito, o jornal Estado de Minas é o defensor da mineiridade. "Otavio Dulci [Dulci, 1984] trata do sentido ideológico da 'mineiridade', traço de predominância e de coesão entre a elite, capaz de manter a tradição, rotina, a ponderação, sobre o risco, a velocidade, a revolução". (SILVEIRA, 2008, p. 33) No caso estudado, a greve representa uma quebra da normalidade, que deixa insatisfeita uma parcela da sociedade que é alinhada ao jornal.

\section{CONSIDERAÇÕES FINAIS}

A ação social é movida pelo conhecimento. É através do saber que o cidadão posiciona-se e constrói a realidade em que vive. $O$ jornalismo, ao prestar-se como veículo da informação, não é um espelho da verdade, já que a verdade, pensada neste trabalho como construção social, é relativa. Há inúmeras verdades que se constroem a cada momento dependendo de situações adversas. Dentro desta perspectiva, o fazer jornalístico, que poderia se pautar pelo enquadramento polissêmico, acaba revelando-se unívoco. O quadro que determina o que será de conhecimento de uma grande maioria de pessoas deveria contemplar a perspectiva social engajada na vertente histórica. $O$ trabalho que possui este cerne supera a efemeridade do "aqui e do agora" e corrobora a humanização dos fatos indo além dos interesses das instituições noticiosas e do mercado. Agir no mundo somente se torna possível quando há algum tipo de informação. Mas a mesma informação pode originar posicionamentos contrários, pode confundir e alterar a vivência social.

Outro aspecto a ser considerado é que não se percebe, no interior das reda- 
ções, um esforço objetivo de promover a especialização dos profissionais para cobertura das pautas sociais em áreas específicas, independente da importância dessas mobilizações para a vida em sociedade. Isto pode ser mais uma confirmação de que a segmentação se orienta mais por critérios mercadológicos e ideológicos do que jornalísticos. O que ocorre muitas vezes, como nesse caso, é que a cobertura da pauta social recebe um olhar enquadrado pelas lentes da linha editorial da empresa, desconsiderando assim outros possíveis olhares.

A partir dessa perspectiva de enquadramento, o propósito desse trabalho foi realizar uma análise do enquadramento fornecido pelo jornal Estado de Minas ao movimento de paralisação dos professores da rede estadual pública de ensino, destrinchando as notícias para mostrar como se deu o processo de desvalorização e "negativação" do mesmo com a formação de duas frentes: os heróis (e as vítimas do processo) e os culpados. Posteriormente, abordou-se o processo histórico de constituição do jornal e trabalhos que tratam da linha editorial do impresso, assim a análise que se realizou foi justificada e recebeu ênfase contextual adjacente.

O imenso espaço dedicado pelo jornal ao movimento grevista não expressou, todavia, uma pluralidade de fontes no processo da representação jornalística. Ficou evidente que a visibilidade conferida pelo impresso ao movimento grevista poderia proporcionar uma falsa ilusão de que a cobertura estava sendo ampla, entretanto ao analisar os enquadramentos das matérias observou-se que as muitas vozes utilizaram o mesmo discurso e que à voz dissonante (os grevistas) foi reservado um pequeno e quase invisível espaço de representação noticiosa.

\section{REFERÊNCIAS}

ALBUQUERQUE, Afonso de. Manipulação editorial e produção da notícia: dois paradigmas da análise da cobertura jornalística da política. In: Antônio Albino Rubim et al. (Orgs.). Produção e Recepção dos Sentidos Midiáticos. Petrópolis: Vozes, 1998.

BERGER, Crista e TAVARES, Frederico M.B. Tipologias do acontecimento jornalístico. In: BENETTI, M. e FONSECA, V. P. S. (orgs). Jornalismo e Acontecimento: Mapeamentos críticos, Florianópolis: Insular, 2010.

ELIAS, Norbert. A sociedade dos indivíduos. Rio de Janeiro: Jorge Zahar Ed., 1994.

FRANÇA, Vera Veiga. Jornalismo e vida social: a história amena de um jornal mineiro. Belo Horizonte: Ed. UFMG, 1998. 
NORA, Pierre. O regresso do acontecimento. In: LE GOFF, Jacques. Fazer História. São Paulo: Bertrand, 1974.

MAFFESOLI, Michel. A Transfiguração do Político: a tribalização do mundo. Porto Alegre: Sulina, 2005.

MARQUES, Ângela Cristina Salgueiro. Relações entre comunicação, estética e política: uma abordagem pragmática. Anais do XX Compós - Associação Nacional dos Programas de Pós-Graduação em Comunicação. Porto Alegre, 2011. Acessível em: < http://www.compos.org.br/pagina.php?menu=8\&mmenu=0\&fcodigo=1608> . Acessado em: 14 set. 2011.

MENDONÇA, Ricardo Fabrino. Movimentos sociais como acontecimentos: linguagem e espaço público. Lua Nova - Revista de Cultura e Política. N. 72. p.115-142. São Paulo, USP, 2007.

MORETZSOHN, Sylvia. Pensando contra os fatos: jornalismo e cotidiano: do senso comum ao senso crítico. Rio de Janeiro: Revan, 2007.

PORTO, Mauro P. Enquadramento da Mídia e Política. In: RUBIN, A. A. C. (org.). Comunicação e política: conceitos e abordagens. Salvador: EDUFBA/UNESP, 2004.

QUÉRÉ, Louis. Entre facto e sentido: a dualidade do acontecimento. Trajectos - Revista de Comunicação, Cultura e Educação. N. 6. p. 59-75. Lisboa, 2005.

.RANCIÈRE, Jacques. A partilha do sensível: estética e política. São Paulo: EXO experimental org.; Ed.34, 2005.

SILVEIRA, Ramiro Queiroz. Linha editorial e poder legislativo: o jornal Estado de Minas e a Assembléia Legislativa de Minas Gerais. Monografia (Graduação em Ciências Sociais). Belo Horizonte: Universidade Federal de Minas Gerais, 2008. Disponível em:< http://www.opiniaopublica.ufmg.br/biblioteca/Monografia\%20Ramiro\%20Queiroz.pdf.> Acesso em: 06 dez. 2011.

Jornal Estado de Minas

Edições: 6 de agosto de 2011, sábado. № 25.384;

9 de agosto de 2011, terça-feira. $N^{\circ} 25.387$;

10 de agosto de 2011, quarta-feira. $\mathrm{N}^{\circ} 25.388$;

12 de agosto de 2011, sexta-feira. No 25.390;

17 de agosto de 2011, quarta-feira. № 25.395;

18 de agosto de 2011, quinta-feira. № 25.395;

24 de agosto de 2011, quarta-feira. № 25.400;

25 de agosto de 2011, quinta-feira. N²5.401;

27 de agosto de 2011, sábado. N²5.403;

30 de agosto de 2011, terça-feira. № 25. 406; 
$1^{\circ}$ de setembro de 2011, quinta-feira. $N^{\circ} 25.410$;

6 de setembro de 2011, terça-feira. N²5.415;

15 de setembro de 2011. quinta-feira. № 25.425;

17 de setembro de 2011, sábado. №25.427;

24 de setembro de 2011, sábado. º 25.429.

RECEBIDO EM: 26/05/2013

ACEITO PARA PUBLICAÇÃO: 16/12/2013

\section{Marta Regina Maia}

Professora Adjunta III do curso de Jornalismo da Universidade Federal de Ouro Preto (UFOP), Mariana, Minas Gerais, Brasil. Atualmente faz Residência Pós-doutoral na Universidade Federal de Minas Gerais (UFMG). Líder do Grupo de Pesquisa “Jornalismo, Narrativas e Linguagens" (CNPq).

\section{Maria Aparecida Pinto}

Mestranda em Comunicação na Universidade Federal de Minas Gerais (UFMG), Belo Horizonte, Minas Gerais, Brasil. Graduada em Jornalismo pela Universidade Federal de Ouro Preto (UFOP). Integrante do Grupo de Pesquisa "Jornalismo, Narrativas e Linguagens" (CNPq). 
